1st International Conference - Global Ethics - Key of Sustainability (GEKoS) | May 15th, 2020 | Bucharest, Romania

\title{
The Role of Public Policies and Economic Instruments in Stimulating the Circular Economy
}

\author{
Gabriela Iuliana PARASCHIV (GANEA), \\ Stefania-Rodica HUBEL (ANGHEL)
}

https://doi.org/10.18662/lumproc/gekos2020/29

How to cite: Paraschiv (Ganea), G.I., \& Hubel (Anghel), S.-R. (2020). The Role of Public Policies and Economic Instruments in Stimulating the Circular Economy. In A. Grigorescu \& V. Radu (vol. ed.), Lumen Proceedings: Vol. 11. 1st International Conference Global Ethics - Key of Sustainability (GEKoS) (pp. 283-294). Iasi, Romania: LUMEN Publishing House. https://doi.org/10.18662/lumproc/gekos2020/29 


\title{
The Role of Public Policies and Economic Instruments in Stimulating the Circular Economy
}

\author{
Gabriela Iuliana PARASCHIV (GANEA) ${ }^{1^{*}}$, \\ Stefania-Rodica HUBEL (ANGHEL) ${ }^{2}$
}

\begin{abstract}
Although the concept of circular economy is still very young, the need to slow down the consumption of resources is well known, from the moment the process of globalization began to take shape, in the early 1980s; thus, developed countries have taken many steps in the process of establishing public policies that anchor in a daily reality the concept of circular economy, thus ensuring its progress through a well-developed legislative system, economic instruments and fiscal measures. designed to create an optimal environment for economic growth and maximize the benefits of its implementation. This article aims to highlight the progress made in establishing public policies related to the circular economy - an integral part of the concept of sustainable development, thus following the process of transition from the so-called "linear economy" to a circular economy, which aims to optimizing resource consumption and harmonizing the long-term sustainable development needs of mankind. In this sense, the paper presents a review of existing policies at global, regional and local levels and their role on the transition to the new economy, the main objective being to identify policies that are transmissible, as well as an analysis of the evolution over time. them. At the same time, the aim is to outline a vision on the existing opportunities by:

- Estimating the potential impact of policy-making by states that are in a more early stage in this transition process taking into account the similarity between states;

- Mapping the benefits of policies already implemented in states with similar conditions;

- Interconnectivity with other priorities of the legislative body (job creation, improving the quality of life of citizens, etc.)
\end{abstract}

Keywords: Circular economy; public policies; transition; resources.

\footnotetext{
${ }^{1}$ Bucharest University of Economic Studies, Romania, gabriela.iuliana.ganea@gmail.com

2 Bucharest University of Economic Studies, Romania, anghel.st77@yahoo.com

* Corresponding author.

(C) The Authors, LUMEN Conference Center \& LUMEN Proceedings.

Selection and peer-review under responsibility of the Organizing Committee of the conference
} 


\section{Introduction}

The evolution of state economies also involves improving people's lifestyles, which involves the purchase of various appliances and a change in diet, including many products that help create an appearance of belonging to a certain social class. At the same time, this change in lifestyle implies a more regular use of personal cars as a means of transportation. All these elements obviously contribute to a greater use of resources, and in most cases this consumption is not achieved in a sustainable way so we encounter an even greater imbalance due to these exchanges [10].

Although the intention of the world economies to move to a circular economy is clear, the measures taken in this direction are already evident in developed countries, while developing economies, which are in the so-called boom of consumption, are still in the early stages of establishing transitional public policies. In this sense, it is obvious that measures are taken by the states involved, so that the circular economy ensures the most sustainable consumption of the resources involved in these processes, taking examples from states that have already gone through this process, based on similarities or economic potential.

From the point of view of profitability, an analysis of profit in the new economic model is required, taking into account its special character, namely the reintegration of the resources used in the economic cycle.

Viewed at the macro level, in the circular economy profit is seen as "the difference between the income generated by the sale of a production and the opportunity cost of the inputs used" [6]. As a derivative of this definition, there is a need to implement the business ethics of the circular economy, having direct implications in the policies adopted by states, but mainly involves the application of these policies in developing countries.

"Business ethics (in the circular economy) is the study of appropriate business policies and practices regarding potentially controversial issues, such as corporate governance, privileged trading, corporate social responsibility, etc." [7]. Thus, in analyzing the role of public policies and other economic instruments, the whole situation must be viewed from an ethical point of view, as this can have various implications, such as influencing regulations, and at the same time can serve as a method of to fill the ethical gaps in today's business environment.

\section{The role of public policies and economic instruments}

Unlike the so-called linear economy whose primary goals are GDP growth and economic development, not taking into account the impact on the environment, resources or social responsibility of both the consumer 
and the producer, the circular economy is based on three known principles for limiting environmental impact: reduction at source, reuse and recycling, which cover both the production and the consumption part, making each member of society responsible and a participant in the development of the economy.

If in the linear economy it is easy to highlight the ethical errors, reaching the point of calling this model "from swing to grave", the circular one gave birth to a model "from swing to swing" [12] thus highlighting the status of continuous resource of most of the resources used as a result of the application of the 3 Rs.

In order to correct these defects, policies and economic instruments are pursued that aim mainly at stimulating the circular economy, but also at establishing new ethical relations that pursue topics such as regulation, government support, corporate governance and social responsibility.

Economic policies and instruments used to stimulate the circular economy can be grouped into three main categories: regulation, taxation and government support.

Table 1. Summary - Economic policies and instruments used to stimulate the circular economy

\begin{tabular}{|c|c|c|c|}
\hline \multirow{7}{*}{ 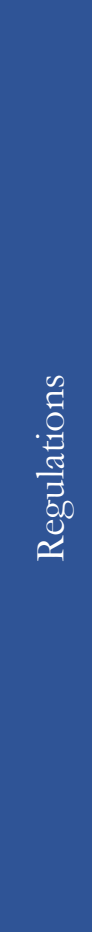 } & \multirow{2}{*}{ 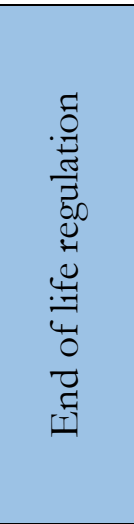 } & $\begin{array}{l}\text { Waste } \\
\text { management }\end{array}$ & $\begin{array}{l}\text { - Using the life cycle approach } \\
\text { - Prohibition of landfills or incineration } \\
\text {-Prohibition of the export of residual } \\
\text { materials }\end{array}$ \\
\hline & & $\begin{array}{l}\text { Resource } \\
\text { efficiency }\end{array}$ & $\begin{array}{l}\text { - Reuse and recycling } \\
\text { - Treatment of biodegradable materials } \\
\text {-Elimination / reduction of chemical } \\
\text { fertilizers } \\
\text { - Water management } \\
\text {-Extended Manufacturer Liability } \\
(\text { EPR) }\end{array}$ \\
\hline & \multirow{3}{*}{ 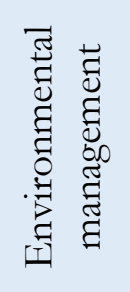 } & $\begin{array}{l}\text { Industrial } \\
\text { production }\end{array}$ & $\begin{array}{l}\text {-Improving processes, products and } \\
\text { services }\end{array}$ \\
\hline & & $\begin{array}{l}\text { Dangerous } \\
\text { substances }\end{array}$ & $\begin{array}{l}- \text { Reduced use } \\
\text {-Increased control }\end{array}$ \\
\hline & & $\begin{array}{l}\text { Renewable } \\
\text { resources }\end{array}$ & $\begin{array}{l}\text {-Increasing renewable energy sources } \\
\text {-Energetic efficiency }\end{array}$ \\
\hline & \multirow{2}{*}{ 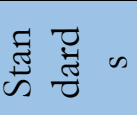 } & Ecodesign & - Setting minimum requirements \\
\hline & & Labeling & - Validation of the origin of the \\
\hline
\end{tabular}




\begin{tabular}{|c|c|c|c|}
\hline & & & products \\
\hline & & Standards & -Minimum quality guarantee \\
\hline & 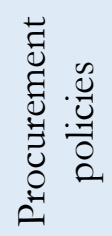 & $\begin{array}{l}\text { Government } \\
\text { procurement }\end{array}$ & $\begin{array}{l}\text { - Procurement based on a responsible or } \\
\text { environmentally friendly procurement } \\
\text { policy by government authorities }\end{array}$ \\
\hline 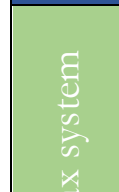 & 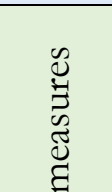 & $\begin{array}{l}\text { Waste } \\
\text { management }\end{array}$ & $\begin{array}{l}\cdot \text { Extended producer responsibility } \\
\text { (EPR) } \\
\text {-Extended consumer responsibility } \\
\text { - Carbon market }\end{array}$ \\
\hline E & 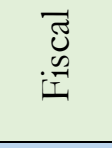 & Taxation & $\begin{array}{l}\text {-Landfill tax } \\
\text {-Eco-taxation (eg taxation of non- } \\
\text { renewable resources) }\end{array}$ \\
\hline & $\vec{E}_{b}$ & Information & $\begin{array}{l}\text {-Identifying best practices } \\
\text {-Stakeholder awareness }\end{array}$ \\
\hline 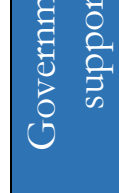 & 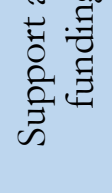 & Funding & $\begin{array}{l}\text { - Direct financing } \\
\text { - Help in finding funding } \\
\text {-Support for research and development } \\
\text { - Residual material subsidies }\end{array}$ \\
\hline
\end{tabular}

Sources: [16], [9], [5], [17], [4], [3], [18]

\subsection{Regulations}

The government can, through its regulations, directly influence how waste materials will be processed and set standards in this regard. According to the results of the study by the Wupperteal Institute Group, Thinkstep and Fraunhofer, the presence of political brakes slows down the emergence of economic opportunities. The study identifies barriers, obstacles or legislative gaps, potential markets for inaccessible or underperforming circular economies. Constraints are not just about a specific policy but rather about a set of regulations. Also, in order to remove certain barriers, it is necessary to restore the balance between the different policies [1].

\subsubsection{End of life regulation}

End-of-life regulations are implemented in various strategies, including the efficient use of upstream resources and downstream waste management. Waste management policies are mainly aimed at avoiding the 
disposal of such materials and reducing the volumes destined for disposal sites. Europe, China and Japan apply, with some variations, the principles of 3Rs, enshrined in their waste management laws.

The Netherlands, targeted seven pilot sectors (textiles, paper and board, construction and demolition debris, aluminum, PVC, bulky household waste and food waste), which helped to reduce the impact by $20 \%$ over the life cycle, based on among others, on the volume in tons of waste materials and pollution of toxic substances [2]. Resource efficiency policies contribute to end-of-life efforts. Actions are based on reuse and recycling.

In Europe, the Directive on waste electronic and electrical equipment (WEEE) in particular, as well as the Directive on Non-Life Vehicles (VFV), aim to make European producers responsible for the guidelines and regulations to be followed for their products, which is a type of "Extended Manufacturer Liability" (EPR) measure [9].

The EU also has rules on the use and free movement of fertilizers made from primary and secondary materials (recovered nutrients), to encourage the transformation of organic waste and derived products into economic potential; has regulations aimed at better integrating them into water reuse, planning and management. Other regulations on resource efficiency include packaging, paper and board, household appliances, batteries and accumulators, and medicines. These laws generally impose binding measures and sometimes incorporate extended producer responsibility agreements by financing the collection [2].

\subsubsection{Environmental management}

Environmental management takes different forms and measures within industrial systems and processes. In order to reduce the environmental footprint of product design, Europe has implemented a Regulation (REACH) for the control of dangerous substances in Europe (CIRS).

Mechanisms, such as subsidized tariffs, encourage investment and technology development as well as supplyrenewable energy to reduce dependence on non-renewable and polluting energies [15].

\subsubsection{Standards}

Standards are forms of quality assurance or compliance with preestablished criteria and serve as a lever to facilitate transactions between 
stakeholders. Standards can also be issued by entities other than governments, such as industry associations or non-governmental organizations (NGOs).

The European Union adopted an ecodesign directive in 2005, which provides a framework with minimum requirements for energy-efficient products.

Labeling allows consumers to be informed based on the given criteria [4]. In other cases, labeling serves as a tool for communicating and differentiating products or communicating product characteristics, according to certain laws.

To encourage the reuse and increase the shelf life of products, Europe and Japan have adopted standards for recycled and sold products online (new and used). The Japanese Industrial Standards Committee (JIS) has established a program of measures to standardize the reuse of recycled products, but also to facilitate their dissemination and use [2].

\subsubsection{Procurement policies}

Governments can implement purchasing policies that require public sector organizations to choose products that meet certain environmental criteria. Given that purchases account for 19.9\% of GDP in Europe, the impact of these policies is major.

Green purchasing policies are implemented by the governments of Japan, Taiwan, South Korea, Malaysia and the USA [11]. In the United States, the priority of NASA and the Pentagon are the offers for the purchase of material goods arising from a green procurement policy [14]. Finally, public procurement policies that require certain procurements, respecting a number of environmental criteria, contribute to the establishment of the circular economy. Responsible purchasing policies are applied by the Japanese, Taiwanese, South Korean, Malaysian and American governments.

\subsection{Fiscal measures}

In addition to regulation, governments can use certain fiscal measures that, among other effects, will impose a cost on externalities associated with resource development.

The concept of extended producer responsibility is based on the polluter pays principle and gives producers responsibility for the 
environmental impact of the end of life of products, while encouraging the reduction of waste materials.

In turn, the incentive pricing system empowers consumers by imposing a tariff on waste materials based on weight or volume.

\subsection{Support and funding}

Other government levers can more or less directly contribute to creating the optimal conditions for the transition to a circular economy. These include making circular economy information available to the target audience. The European Commission is adapting its reference documents to the best available technical reference documents (BREFs) specific to certain sectors, by incorporating elements of the circular economy. Germany has created an information platform on innovative technologies, which includes resource efficiency [3].

Some levers take the form of funding or assistance in obtaining funding. Government support for the transition is critical to the success of the process, as it reduces risk and ensures that investments align with economic and environmental development goals [3]. In Europe, a platform has been set up bringing together the European Commission, the European Investment Bank and financial market actors and businesses to support increased efforts to raise awareness of the circular economy among businesses and to stimulate investor interest in circular projects.

Considered the main tool for the development of a green economy in the Netherlands, the Green Deal program facilitates the creation of innovative projects in society, helps to implement circular projects and removes certain obstacles to the development of a green economy [2],

The "Eco-Town" program implemented in Japan, facilitates the establishment of industrial symbiosis by financing local communities and loans from the Development Bank of Japan. Waste exchanges, the operation of which is similar to financing, are particularly useful and necessary for the creation of an industrial symbiosis

\section{The impact of public policies}

The interest in the circular economy is easy to see in developed countries, especially those interested in the subject, such as China, Japan, as well as countries in Western Europe where special attention is paid to the creation of public policies. However, if progress can be tracked in developed countries and benefits can be seen as a result of the measures taken, the potential of developing countries is still ignored. 
In developed countries, public policies are introduced with the ultimate goal of achieving a sustainable cycle of production and consumption, but for this to become a reality, significant investments are needed in adapting existing means or replacing them with sustainable means (including destroying old ones for creating new ones).

Actions such as improving infrastructure, adapting factories to be able to produce without wasting resources and adopting a sustainable lifestyle prove to be costly and therefore the material benefits are seen after a longer period. Instead, in developing countries, development policies and principles can be adopted that include from an early stage measures already adopted in developed countries, thus achieving not only superior quality but also low costs, thus contributing. to meet the needs of the population and fuel development, but without generating an increase in emissions or pollution and at the same time preventing the irresponsible use of resources [8].

In Europe, the model proposed by the EU, which ensures the transparency of the measures adopted by each Member State, facilitates the transfer of policies between states, thus succeeding in accelerating the adoption of policies that support the development of industries in a sustainable way. For example, in Romania, a country belonging to the former communist bloc and characterized by a lack of transparency in the implementation of public policies, there are improvements in the quality of economic development by adopting public measures that encourage the opening of non-waste factories and follow measures. minimizing the resources used by granting aid (taxes, space, etc.), resulting in the opening of factories by multinational companies such as Procter \& Gamble, IKEA, Coca-Cola.

\section{The transition to a circular economy in Romania}

At national level, starting with 2008, Romania has in force the National Strategy for Sustainable Development of Romania Horizons 20132020-2030, in which it is established as an objective "promoting sustainable consumption and production practices".

It specifies the economic policies and instruments through which sustainable development is achieved: the introduction of green technologies and the stimulation of eco-innovation, green public procurement, the adoption of regulations on highlighting in BVCs and financial statements of legal entities and other market entities, of the economic indicator "resource productivity". 
For 2030, the Strategy set as its objective: "the approximation of the average level achieved at that time by EU member states in terms of sustainable production and consumption".

The goal of integrated waste management is to move from landfilling to selective collection and recovery of a greater proportion of recyclable waste, including through the conversion of organic waste into compost, and the exclusive use of landfills for the urban environment green.

Romania currently has a waste management system still largely based on landfill. Currently, there are a number of difficulties, with Romania having the highest waste disposal rate in the $\mathrm{EU}(72 \%)$ which is well above the EU average of $25.6 \%$.

Eurostat data show that there is a positive development in the collection of recyclable waste, but that progress is too slow to ensure that the objectives (targets) of the specific European directives are met in the near future. Romania has to overcome a large gap in terms of developing its own collection infrastructure, streamlining recycling, and reusing its resources.

Table 2. Ethe evolution of waste recycling rates applicable to Romania, for the period 2005-2016

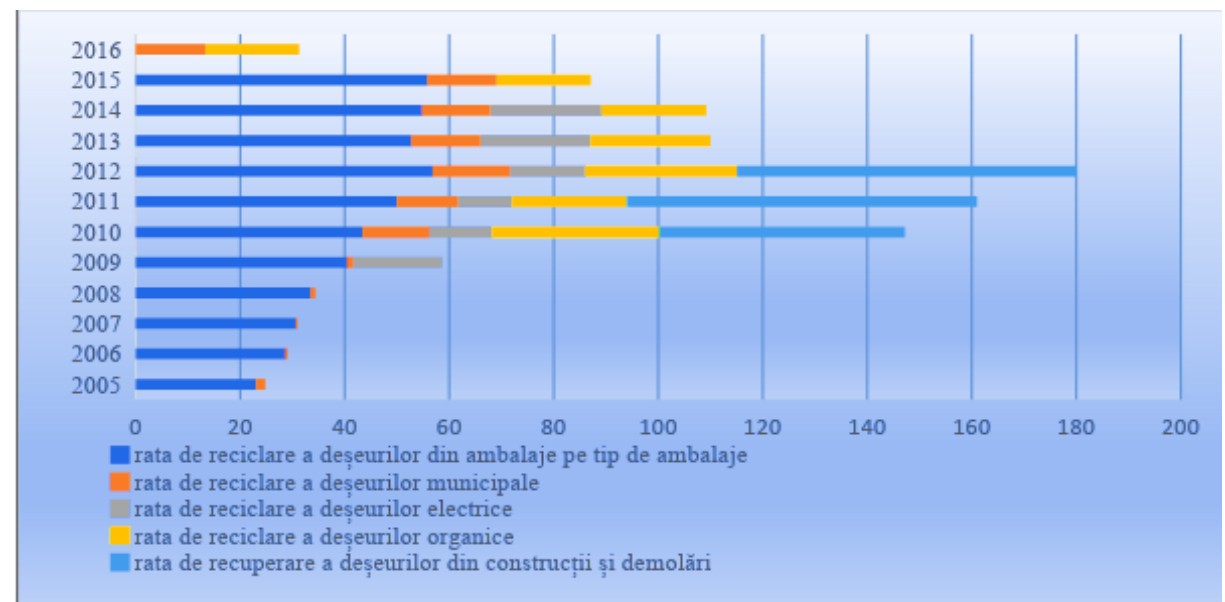

Source: [19]

The Structural and Cohesion Funds have an important role to play in implementing the circular economy and the concept of resource efficiency. In this respect, the new post-2020 multiannual financial framework is an opportunity that should not be underestimated due to the low absorption rate on various types of funds. The proposal aims to increase 
cohesion funds by $8 \%$ in the future multiannual budget (from $€ 25.2$ billion in $2014-2020$ to $€ 27.2$ billion in the post-2020 period).

It is necessary, at national level, to introduce new lines of financing the circular economy, in particular for the implementation of policies, technologies or processes at sectoral level, for the efficient use of resources, or for the area of synergies of the circular economy. As an example, throughOperational Program for Fisheries and Business Funding is provided to support the accreditation of national testing laboratories for complex analyzes for the compost area, the sludge area of wastewater treatment plants to determine the presence of medicines, cosmetics or other traces of pollutants and to determine exactly whether can be used in agriculture.

Local public authorities have an important role to play in designing an efficient collection system, including at source, for all types of waste. For example, the implementation of schemes such as "you pay as you throw" would allow the implementation of the "polluter pays" principle.

In conclusion, for the circular economy to become functional in Romania, the involvement of all public authorities and the economic environment is indispensable.

\section{Conclusions}

The transition to the circular economy does not mean a decrease in economic activity, on the contrary, the elements studied indicate, in addition to reducing the impact on the environment, the high economic potential, especially for developing countries, even having the role of encouraging the development of new industries. However, both institutions and companies need to rethink their business models, including the business model, in order to maximize benefits.

In fact, this transition must be seen and treated as a change of approach at national level to which the necessary time is devoted so that it generates the expected benefits. At present, public policies have a major impact during the transition period. which may be more extensive or more specific to a particular goal, but still at an early stage of creation and implementation; public policies should be debated and adapted to serve the needs of all actors involved.

Certainly a good understanding of the specific characteristics of each local authority will facilitate the choice of strategies and sectors to focus on. The transition to a circular economy should be accompanied by aid programs, incentives, appropriate taxation and favorable legislation, so that it can be fully implemented and succeed in stimulating public and private 
investment while ensuring rigor in on business ethics and ensuring transparency in policy implementation.

The circular economy has a great entrepreneurial potential, as it can contribute to gains in productivity, efficiency and profitability, in addition to stimulating the search for innovation. The use of the circular economy in business models and processes to gain momentum should therefore be able to rely on the development of strategies, analysis tools and financial and regulatory solutions to identify the flow of potential materials, such as and find new uses and commercial points for them. Without being quantified, an advantage of recycling and recovery would be to reduce the sensitivity of companies to changes in the prices of virgin raw materials. This variation poses a risk to the sustainability of enterprises [5], [13].

The circular economy provides an opportunity to stimulate the economy, making it more sustainable and competitive in the long run. It will reduce costs for European industries, lead to investment, create a level playing field and last but not least, multiple environmental benefits.

\section{References}

[1] Bechtel N, Bojko R, Volkel R. Be in a loop: circular economy and strategic sustainable development. School of Engineering Blekinge Institute of Technology Karlskrona, Sweden. 2013

[2] CGDD CGpDD. International comparison of public policies in the circular economy. January 2014.

[3] Ellen MacArthur Foundation. Towards economic circulation vol. 3: Accelerating expansion in global supply chains. 2014.

[4] Ghisellini P, Cialani C, Ulgiati S. A review of the circular economy: the expected transition to a balanced interaction of economic and environmental systems. Into thec. 2016.

[5] Montaigne Institute. Circular economy: reconciling growth and the environment: Institut Montaigne. 2016.

[6] Investopedia. "Advantage". [Online]; 2019 [cited 2020 April 20]. Available from:https://www.investopedia.com/terms/p/profit.asp

[7] Investopedia. Business ethics. [Online]; 2019 [cited 2020 April 20. Available from: https://www.investopedia.com/terms/b/business-ethics.asp

[8] Wellesley L, Preston F, Lehne J. An Inclusive Circular Economy: Priorities for Developing Countries. 2019.

[9] Lieder M, Rashid A. Towards the implementation of the circular economy: a comprehensive review in the context of the manufacturing industry: J. Clean. Prod. 2016.

[10] Norman M, Kent J. New Consumers: The Influence of Affluence on the Environment Washington: USA: Island Press. 2004. 
[11] Preston F. A global redesign: shaping the circular economy. 2012.

[12] Qiao F, Qiao N. Circular Economy: An ethical and sustainable economic development model. Research Gate. 2013.

[13] Rebaud AL. Towards a circular economy. 2017.

[14] Stahel W. Policy for material efficiency - sustainable taxation as a departure from society to follow. 2013.

[15] World Future Council. Entry fees - A guide to one of the best environmental policies in the world. Increasing energy for our future. June 2017.

[16] Technopolis Group, ISI Fraunhofer, Thinkstep \& Wuppertal Institute. Regulatory barriers to the circular economy: lessons from ten case studies. Technopolis Group. 2016

[17] EASAC. Indicators for a circular economy. European Academies' Science Advisory Council. ISBN 978-3-8047-3680-1. 2016.

[18] McKinsey \& Company. The circular economy: Moving from theory to practice. McKinsey \& Company. 2016.

[19] Eurostat. [Online]; 2018 Available from: https://ec.europa.eu/ eurostat/web/circular-economy/indicators. 